Balázs FeKete*

\title{
Practice Elements in the Hungarian Legal Education System ${ }^{* *}$
}

\begin{abstract}
The main aim of this paper is to analyze certain features of the Hungarian legal education system with special regard to the role of practice. In its first parts it highlights those institutional and sociological dynamics that touched upon legal education during the last decades and briefly introduce the reader into the legal background of legal education. Concerning the role of practice the paper examines the role of seminary education compared to the general system of "lectures" as well as the recent constellation of clinical legal education in Hungary in detail. As conclusion, the paper argues that the growth of practice-oriented ways of teaching should lead toward the general acceptance of an educational conception in which theory and practice can work in harmony.
\end{abstract}

Keywords: legal education, clinical legal education, practice in legal education, skill training

\section{General features of the Hungarian legal education}

\section{Historical introduction and some general information}

1. A key feature of the Hungarian legal educational system is its strong historical traditions. The first law school of the country was founded in 1667 as the third faculty of the Jesuit University of Nagyszombat, in the northern part of medieval Hungary. The town of Nagyszombat was also the centre of the Hungarian counter-reformation movement at this time. This university was established by Péter Pázmány, the archbishop of Esztergom in 1635 and it already had two faculties: humanities and theology. Domestic customary law, canon law and Roman law were the main forms taught at the law faculty of Nagyszombat, in harmony with the general trends of legal education in the $17^{\text {th }}$ century. ${ }^{1}$ Hungarian legal education therefore has an almost 350 year long history.

Today eight faculties of law exist in a country with more than 10 million inhabitants with half of them being established following the political changes of 1989. The regional division of Hungarian law schools is relatively balanced as one can find at least one law

* Junior research fellow, Institute for Legal Studies of the Hungarian Academy of Sciences, H-1014 Budapest, Országház u. 30, Hungary, Lecturer, Pázmány Péter Catholic University, Faculty of Law and Political Sciences, H-1088, Szentkirályi u. 28, Budapest, Hungary.

E-mail: fbazsa@jak.ppke.hu

** Hungarian national report submitted to the $18^{\text {th }}$ International Congress on Comparative Law, Section I D. Formation juridique / Legal education-Le rôle de la pratique dans la formation des juristes / The Role of Practice in Legal Education.

1 For a deeper and more detailed discussion of the early centuries of Hungarian legal education, with special regard to the role of comparative law see Péteri, Z.: Teaching of Comparative Law and Comparative Law Teaching. Acta Juridica Hungarica 43 (2002) 255-257; for a general introduction into the history of Hungarian legal education see Nagy Zs.: A magyar jogi oktatás történeti vázlata [A Historical Draft on the Hungarian Legal Education]. Jogelméleti Szemle 2003/3. http://jesz.ajk. elte.hu/nagy15.html; for the history of the oldest faculty of law see Horváth, P.: 300 Jahre Staats- und Rechtswissentschaftliche Fakultät der Budapester Eötvös-Loránd-Universität. Annales Universitatis Scientiarum Budapestinensis De Rolando Eötvös Nominatae Sectio Iuridica 8 (1967) 3-26. 
faculty in each regional centre except Central Transdanubia. ${ }^{2}$ There are three faculties of law in Budapest, the capital city of the country, and this fact appropriately indicates that the heart of Hungarian legal education can be found here.

It is worth mentioning at this point that the institutional dynamics of the Hungarian legal education system went through a "golden age" or "blooming period" from the second half of the 1990's onwards. Four faculties of law was established between 1995 and 2002, ${ }^{3}$ doubling the number when compared to the number of faculties that existed in the socialist era. An additional point of interest is that, of the four law faculties established during the "post-socialist or transitory" period, two of them were directly founded by two Hungarian Christian churches, the Catholic and the Protestant. ${ }^{4}$ Thus both traditional universities and churches anticipated many opportunities in the foundation and management of law schools in the period following the political changes.

2. The number of students participating in legal education significantly increased in parallel to the establishment of new faculties. One can see from the data that in the academic year 1980/1981 law faculties had 4629 students and 4738 in the academic year 1990/1991. ${ }^{5}$ Therefore less than 5000 law students were studying in some of the four law schools yearly during the last decade of socialism. However, in the next decade this number almost tripled as 15776 law students participated in various forms of legal education in the academic year of 1999/2000 increasing to 17935 in the academic year of 2002/2003. ${ }^{6}$ Looking at the number of graduating law students one can point to a similar trend, 899 students graduated in 1980, 741 in 1990, 1881 in 2000 and 3190 in $2003 .^{7}$ The numbers of enrolling and graduating law students have remained more or less constant in the following years. One can conclude therefore from this data that legal education reflects a more broadened and democratic picture than it did during the socialist period.

With reference to the costs of legal education it should firstly be mentioned that in the Hungarian higher education system students can study for free or on a tuition fee basis. A certain number of law students are assisted by the government in the form of a direct financial support every year. However, law schools, as in all the other faculties, are also

2 Faculties per regions, their seats, names and dates of foundation: Western Transdanubia: Györ, Deák Ferenc Faculty of Law and Political Sciences, [(1995) 2002]; Southern Transdanubia: Pécs, Faculty of Political and Legal Sciences of the University of Pécs (1923); Central Hungary: Budapest, Eötvös Loránd University Faculty of Law and Political Sciences (1667), Pázmány Péter Catholic University Faculty of Law and Political Sciences (1995), Károli Gáspár University Faculty of Law (1998); Southern Great Plain: Szeged, University of Szeged Faculty of Law (1872); Northern Great Plain: Debrecen, University of Debrecen Faculty of Law (1996); Northern Hungary: Miskolc, University of Miskolc Faculty of Law (1981).

3 Deák Ferenc Faculty of Law and Political Sciences [(1995) 2002]; Pázmány Péter Catholic University Faculty of Law and Political Sciences (1995); University of Debrecen Faculty of Law (1996); Károli Gáspár University Faculty of Law (1998).

4 Pázmány Péter Catholic University Faculty of Law and Political Sciences (1995); Károli Gáspár University Faculty of Law (1998).

5 Szabó M.: A jogászképzés társadalmi funkciójáról - húsz év múlva [On the Social Function of Legal Education-Twenty Years Following]. In: Szabadfalvi J. (ed.): Amablissimus-Loss Sándor emlékkönyv [Amablissimus-A Volume Dedicated to Sándor Loss]. Debrecen, 2005. 318.

6 Kissné Pap M.: A jogi felsőoktatás néhány jellemzője [Some Features of the Legal Education]. In: Takács P. (ed.): A jogászképzés múltja, jelene és jövője [The Past, Present and Future of Legal Education]. Budapest, 2003. 327-328.

7 Szabó: op. cit. 325. 
allowed to accept students on a tuition fee-paying basis. The tuition fees for a semester range between $130000-200000$ HUF (715-1060 USD) this year. ${ }^{8}$ The ten semester long legal education therefore costs about 7150-10600 USD (based on today's prices) in Hungary if a student can only enroll in a law school on a fee-paying basis.

In the recent past there was a special written entrance exam consisting of history and Hungarian literature for law students, but the system has changed following the introduction of the so-called Bologna model ${ }^{9}$ in Hungary. Nowadays prospective students are accepted on the basis of the results of their high school graduation. The maximum result of high school graduation is 480 points including all the possible bonuses, and the acceptance points this year were between 426-405 for normal places and between 400-172 for the fee-paying places. As a result of this, students with lower results from high school could also be accepted to a law school if they are or their families are able to pay the tuition fee.

3. It is also a characteristic feature of the Hungarian legal education that law school graduates cannot work as an independent practicing attorney or lawyer immediately after graduation. Having worked for three years in a legal position under the supervision of a senior lawyer-mainly an attorney, a judge, a prosecutor or other persons having responsibility in legal work-the trainee or assistant has the right to register for a special examination called the szakvizsga. The underlying idea of this examination is fairly similar to that of the examination for entry into the bar in common law countries, the sole exception is that it is open to candidates coming from other spheres of legal life and it is administered and coordinated by the Ministry of Justice, not by the Bar Associations.

This examination consists of three modules: (i) civil law, family law, economic law and civil procedure; (ii) criminal law, criminal procedure and penitentiary law; iii.) labour law, social security law, constitutional law, administrative law, and the law of the European Community..$^{10}$ A candidate has to choose one subject from which he or she intends to make both a written and an oral exam, while from the other modules the only requirement is a successful exam before a committee composed of professionals. These exams are explicitly to measure the practice skills of the candidates since they have to prepare a submission in the context of a hypothetical case in the written part, ${ }^{11}$ and the subsequent oral exams are also about the discussion of a fictitious case with the members of the committee. ${ }^{12}$

\section{The legal background}

4. There is no special act regulating the requirements for the licensing of law schools in Hungary, but the Higher Education Act of 2005 provides a general framework for their functioning. This act, as the basis of the entire system of Hungarian higher education,

8 It must be mentioned that the average gross monthly income was around 199000 HUF (1050 USD) in 2008. Source: Hungarian Central Statistical Office. http://portal.ksh. hu/pls/ksh/docs/hun/xstadat/xstadat_eves/tabl2_01_25_01i.html

9 The main aim of the so-called Bologna Process is to create the European Higher Education Area by harmonizing academic degrees and quality assurance standards. It began in 1999 with signing of the Bologna Declaration by Ministers of Education of 29 European countries. Cf.: http://www. ond.vlaanderen.be/hogeronderwijs/bologna/

10 Decree of the Ministry of Justice No. 5/1991 (IV. 4) § 5 (1).

11 Ibid. $\S 7$ (1).

12 Ibid. $\$ 9$ (2). 
clarifies general questions such as the establishment of higher education institutions, ${ }^{13}$ the principles of their functioning, ${ }^{14}$ the structure and organs of higher education institutions ${ }^{15}$ and governmental competences in higher education. ${ }^{16}$ Moreover, it provides a detailed regulation on the position of students including their rights and obligations, ${ }^{17}$ it defines the main lines of the exam and grading system, ${ }^{18}$ and also regulates both the right of appeal against university or faculty decisions ${ }^{19}$ and the organization of student bodies and their representation..$^{20} \mathrm{All}$ in all, this act comprehensively rules the sphere of higher education and therefore sets forth a stable legal framework for it; so it could be regarded as the "constitution" of Hungarian higher education.

The Act set up the so-called Hungarian Accreditation Committee to create a regulatory body for the management of the whole system of higher education. This Committee is an independent body and its main aim is the assessment and monitoring of the quality of the entire system of higher education. In doing so, the Accreditation Committee delivers opinions on the different bachelor, master and doctoral formations prior to their governmental recognition as well as regularly-every eight years-monitoring the functioning of every higher education institution from the aspect of the fulfillment of all necessary, mainly personal, physical and financial preconditions. ${ }^{21}$

The Accreditation Committee has a very important position regarding the establishment of faculties since the act explicitly sets forth that prior to creating a new faculty in the framework of an existing higher education institution, a preliminary opinion shall be asked from the Committee. ${ }^{22}$ Therefore, from the aspect of accrediting a law faculty the decisive point is the preliminary opinion delivered by the Hungarian Accreditation Committee since according to the act a new faculty can be only established if the Committee supports it in its opinion. ${ }^{23}$ In the case of a negative or non-supportive opinion the given higher education institution can appeal to the so-called Registration Centre ${ }^{24}$ and then to the Minister of Education who may depart from the opinion of the Committee. ${ }^{25}$

In the opinion of the Accreditation Committee the fulfillment of the so-called minimal conditions-as they are outlined in Appendix 5 of Governmental Decree No. 79/2006 (IV. 5) on the realization of certain articles of the Act of Higher Education-could play a preeminent role. According to this decree the most important conditions for the establishment of a new faculty are the following: firstly, the faculty shall at a minimum incorporate two different levels of formation (bachelor, master or doctoral), secondly,

13 Act CXXXIX of 2005 on the Higher Education $\S 12-18$.

14 Ibid. $\S 19-22$.

15 Ibid. § 23-30.

16 Ibid. § 99-114.

17 Ibid. \$ 46-51.

18 Ibid. $\S 57-61$.

19 Ibid. $\S 73-75$.

20 Ibid. $\$ 77-79$.

21 Ibid. $\S 109$ (1) g and $\S 110$ (1).

22 Ibid. § 30 (6).

23 Ibid. $\S 32$ (10).

24 An agency set up by the Act in order to register higher education institutions.

25 Ibid. $\S 106(2)$. 
a minimum of two hundred students must be enrolled to these formations in the year prior to the submission of the registration claim and lastly, the full tenure of forty teachers is also required. ${ }^{26}$ The first condition in the case of a law school practically means that the future faculty of law has to offer both graduate legal education and doctoral formation-due to the fact there are no LL.B. or LL.M degrees in Hungary but only a five year long, and therefore undivided, lawyer degree.

5. One cannot find a standard course of study at law faculties since the general structure of legal education was regulated in relatively broad terms by the legislator. Law students have ten semesters for their studies and they must collect 300 credits during these five years. It is required to prepare and defend a master thesis at the end of the studies and the passing of four so-called state exams ${ }^{27}$ are also mandatory. In relation to the remaining nine semesters the relevant decree of the Ministry of Education ${ }^{28}$ only outlines the main lines for the curricula of law schools by diving them into three major parts. A legal curriculum must contain (i) basic studies ${ }^{29}$ (80-110 credits), (ii) professional studies ${ }^{30}$ (115-130 credits) and (iii) elective studies ${ }^{31}$ (30-50 credits). Besides these guiding principles and credit numbers, law schools are almost absolutely free to compose their curriculum, the only thing that they must respect is the earlier general structure.

This decree also defines that law students must fulfill an obligatory period of apprenticeship of 6-12 weeks in order to facilitate the formation of their practical skills. This period could be spent in the judiciary, public administration or in other fields as is determined by the curriculum of the given law school. Law faculties therefore have broad opportunities to offer externships to their students. It should be stated that this is the sole point where the legislator mentions practice in the most general sense, in the other parts of the decree one cannot find any reference to it. Hence, one may conclude that the practical aspects of legal education were not the primary focus of the legislator when it created its basic principles.

On the basis of this general introduction we can acknowledge that the current regime of governmental regulations barely deals with the role of practice in legal education, the sole exception is the mentioning of the obligatory period of apprenticeship as a requirement. The introduction of practice elements into the curriculum remains the responsibility of law schools, and therefore their diffusion depends mainly on the policies of a given faculty.

26 Governmental Decree No. 79/2006 (IV. 5) on the realization of certain articles of the Act on the Higher Education, Appendix 5.

27 The first three of these state exams are same at all the faculties: private law, public law and criminal law, but the last one could differ depending on the given faculty since it could be international and European law or legal theory.

28 Decree of the Ministry of Education No. 15/2006 (IV. 3) on the requirements of bachelor and master degrees.

29 For instance: general social science, professional language, latin, basic jurisprudence, legal theory, legal sociology, legal history classes.

30 For instance: private law, constitutional law, administrative law, criminal law, international law, European law classes.

31 For instance: in-depth classes related a given legal institution, ethical studies and comparative law classes. 


\section{Practice elements in the Hungarian legal education}

6. The guidelines kindly provided by the general reporter suggest that practice elements could be conceived of in a relatively broad sense. As a first step it is worthwhile separating two fundamentally different dimensions: the aforementioned period of compulsory apprenticeship which is dedicated to gaining experience of professional life and the different ways and methods of offering "practical" education in the curriculum of a given faculty. This paper will firstly scrutinize certain characteristics of this externship period, then it will turn to the various forms of "in-house" practical training, that is to say to those courses in which some practice elements are included.

At the outset, it must be mentioned that law schools are absolutely free in the determination of the detailed rules of this externship period. In these regulations law schools generally appoint a teacher or a professor-practically called a coordinator-who is responsible for the administration and coordination of the whole program. The crucial question of this period is the place of the apprenticeship i.e. which institutions are willing to accept and integrate law students for 30 workdays or six weeks into their life. It is obvious that a prestigious international law firm can offer very different experience than, for instance, an administrative agency in a small town. Many faculties handle this problem with the help of different framework cooperation agreements concluded among the given law school and various administrative bodies, courts and other legal institutions. Of course, students can choose institutions as place of externship other than these official partners, but they must organize it on their own in this instance. Normally law schools are flexible in accepting various propositions coming from their students. The only thing that students must keep in mind is that all the necessary administrative requirements-an agreement to accept the student, a report about his or her work, signed by a responsible person-must be fulfilled.

Accordingly, law students can fulfill this obligatory period by participating in the work of various institutions, e.g. courts, administrative agencies and national or international law firms. An example of this institutional agreement-the Faculty of Political and Legal Sciences of the University of Pécs concluded cooperation framework agreements with the County Court of Pest, that of Baranya, the Parliamentary Commissioners' Office and the regional inspectorate for the environment, nature and water. ${ }^{32}$ Thus the law students of this faculty can choose from a relatively broad "menu", since the various offers of the law school comprise of judiciary, public administration as well as legal assistance experience, and they can even look for other options independently.

7. The traditional setting for teaching certain dimensions of legal practice are the socalled seminars or seminary classes in the general curriculum. In order to understand the peculiarities of the Hungarian system, we must firstly look at the two ways of law school teaching. Firstly, law schools offer to all students who fulfil each necessary precondition, general courses which are normally managed by a professor or professors. These courses are accessible to all students and they are basically comprehensive lectures provided by a professor. They generally work as a one-way channel, since the main emphasis lies on the lecture of the professor and does not include the active participation of students. That is why these classes are usually referred to as "lectures" in the informal language of both students and professors.

32 Announcment of Dr. Cs. Herger, coordinator of the externship program (07. 03. 08). http:// www.law.pte.hu/tartalom/110 
However, to provide a different kind or quality of education than that of passive listening and making notes, law schools also offer courses dedicated to small groups of students, maximum 20 or 25 students depending on the institution, and these kind of classes are generally called seminars. These seminars are always linked to the "lectures" and their main aim is to interactively discuss the subject in a detailed manner. It is also worthwhile mentioning that these seminars are often taught by younger teachers, mainly assistants or lecturers ${ }^{33}$ which makes possible the creation of a more informal, open and cooperative atmosphere compared to the general features of "lectures". For instance, at the Pázmány Péter Catholic University Faculty of Law and Political Sciences the general course or the "lecture" entitled Private Law I.-this class is about the theory, history and general principles of private law as well as personal law-seminars of Private Law I. are always attached. Finally, it should also be mentioned that the attendance requirements of seminars are always more strict than those of the "lectures" and if someone has already chosen a general class it might also be compulsory to choose a seminar from the same subject at many faculties.

In this regard seminars could be the ideal place for teaching practical legal knowledge due to the small number of students and their specialized nature. Ideally, these classes are about the interactive discussion of case-law related to the main subject. ${ }^{34}$ During these in-depth case analyses, students could be familiarized with the reasoning of courts as well as the general legal arguments. However, it must also be borne in mind that the success of the course is always dependent on the capacities of the given teacher; therefore it is impossible to generally assess this seminary education system. With a good and wellprepared teacher these classes can substantially enrich the practical, case-law oriented knowledge of the students.

However, one of the manifest weaknesses of seminars is the fact that these classes are normally devoted to the national case-law and thus they usually miss the comparative approach. As a result, students cannot gain a broader view on a given legal problem by definition, which would help them to recognize that the general principles behind the various legal solutions could often be almost the same or very similar. ${ }^{35}$ Additionally, these classes are exclusively aimed to bring students closer to the case-law, thus they do not intend to improve the practical skills that they will require in their future professional life, e.g. writing memorials or pleading before the courts. Therefore, one can generalise that the seminary teaching method can overcome the manifest disadvantages of the "lecture" method as they include detailed case-law analyses and have a strong interactive element. But this way of teaching has usually nothing to do with the improvement of the practical skills.

8. Clinical legal education is a relatively new element in the curricula of Hungarian faculties of law. The first of these courses started in 1996 at the Eötvös Loránd University Faculty of Law and Political Sciences, ${ }^{36}$ and other legal clinics have been founded in Györ,

33 A certain part of those who teach seminary courses even could come from the "practice", as for instance attorneys, prosecutors or even judges depending on the policy of the given law school.

34 For a detailed analysis of the advantages and disadvantages of the so-called case-method see: Jakab, A.: Dilemmas of Legal Education-A Comparative Overview. Journal of Legal Education 2007/2, 253-265.

35 Cf.: Schlesinger, R. B.: The Common Core of Legal Systems. In: Zweigert, K.-Puttfarken, H. J.: Rechtsvergleichung. Darmstadt, 1978. 249-269.

36 http://jogklinika.cjb.hu 
Szeged, Debrecen and Miskolc. More than half of all law schools now offer some kind of clinical legal education to law students, and it can be regarded as a considerable achievement in the field of practical education.

As an illustration of the work and effectiveness of the clinical legal education in Hungary it is worthwhile examining two of them in detail. The most comprehensive practical legal education is offered by the legal clinics hosted by the Eötvös Loránd University Faculty of Law and Political Sciences. These legal clinics are administered by an independent foundation - the Jogklinka (legal clinic) and Street Law Foundation-and their financial background has been provided by external donors such as Open Society Foundation, Soros Foundation and Ford Foundation since their establishment. ${ }^{37}$ It is very important to emphasize that due to this financial independence the legal clinics provided all of their services-from education to legal assistance-to the law faculty free of charge.

According to the Foundation, legal clinics have various but closely interrelated goals. They are aimed at providing legal services for socially disadvantaged people, to improve the quality of legal education by organizing practice-oriented and skill-training focused courses and to prepare comparative and critical analyses about the normal functioning of the legal system. ${ }^{38}$ In addition to these major aims the founders also defined some supplementary goals: that these courses are dedicated to enhancing the social sensitivity of students and their social responsibility; that they also assist in the deepening of the values of democracy and those of the rule of law; and that they can help in the development of professional skills; moreover that these classes are also able to support equality before law by providing free legal assistance for those who need it. ${ }^{39}$ The improvements of the practical thinking and skills of law students as well as the promotion of values such as social responsibility and equality before law are viewed equally as the key focus of this program.

Currently six different legal clinics operate at the Eötvös Loránd University Faculty of Law and Political Sciences, and each of them is an elective course of at least two or even more semesters. Each legal clinic is focused on a special segment of legal affairs and their programs could be divided into three consecutive parts: improvement of the theoretical knowledge, specific skill training such as conducting interviews with clients, fact investigation etc., and learning through the general practice. It must also be mentioned that the teaching team of these legal clinics is always a special composition of university teachers as well as practicing professionals. Depending on the area of the various legal clinics one can find attorneys, judges, or other professionals e.g. psychologists or aftercare experts within the teachers excluding professors or assistant professors. Obviously students would profit a lot from the personal meetings and supervision of such experts in the field of practical thinking and skills.

The eldest is the Criminal Law legal clinic, which offers free legal assistance to disadvantaged and young people. According to the data this legal clinic deals with approximately 60 cases yearly, the majority of which are related to young and roma people. The second legal clinic is called the Nonprofit Law legal clinic dealing mainly with cases related to civil organizations such as establishment, tax problems or legal assistance. The third legal clinic program is also related to criminal law since it is focused on the aftercare of former prisoners. In the framework of this Aftercare Law legal clinic students become

37 http://www.jogklinika.cjb.hu/alapitvanyunkrol.html

38 A jogklinikák bemutatása [Introduction to the various legal clinics]. http://www. jogklinika.cjb.hu/jogklinikak.html

39 Ibid. 
familiar with the difficulties of reintegration as well as the socio-cultural effects of imprisonment. The fourth legal clinic in this web of clinical legal education is the Labour Law legal clinic, its work is focused on a very special target group since this legal clinic helps people with epilepsy to integrate into the labour market. In this special assistance activity the legal clinic cooperates with a foundation (Foundation Umbrella) specializing in helping and assisting people with epilepsy. The "youngest" legal clinic, which was established in 2003, is the Rights of the Child legal clinic. As is obvious from its name, the main goal of this legal clinic is assistance in the protection of children, with special regard to their rights as they are expressed in Hungarian law. The last legal clinic could be regarded as the most peculiar one since its aim is teaching law in high schools and in various penitentiary institutions. Its name is the Street Law legal clinic and it offers a comprehensive education about the different methods of law teaching in secondary education. ${ }^{40}$

As one can see this "web" of clinical legal education could be regarded as quite complex and sophisticated since it includes six specialized clinics and many really interesting issues from the teaching of law to labour law assistance. The varied specialization and appeal of this form of education as well as the choice of interesting and hot topics could be one of the main reasons that about 100 students enrolled to these legal clinics every year. ${ }^{41}$

Compared to this system of legal clinics the Freedom of Information legal clinic-also included in the curriculum of the Eötvös Loránd University Faculty of Law and Political Sciences-might be regarded as a slightly more modest but also very interesting enterprise. This legal clinic is one of the newest legal clinics in the country since it was started in the first semester of 2008 as a two-semester long elective course. As one can clearly see from its name its aim is to familiarize students with the practical problems of the law with special regard to the access of public data and information. ${ }^{42}$ There is a broad institutional background behind this legal clinic since six civil associations dealing with a wide-range of affairs related to public data and information-Open Society Justice Initiative, Association for Public Data, Reflex Environmental Protection Association, Enviromental Management and Law Association, Eötvös Károly Institute and Hungarian civil Liberties Union-participate in its program mainly by offering internships for the enrolled students.

One should state that the establishment of this system of legal clinics has only successfully begun in the last years. This process is properly illustrated by the fact that an Administrative and Constitutional Law legal clinic related to the University of Szeged Faculty of Law as well as an Anti-discrimination legal clinic hosted by both the University of Miskolc Faculty of Law and Eötvös Loránd University Faculty of Law and Political Sciences also started to work in 2007 and in 2009. This fast proliferation of legal clinics in various law schools proves that there is a constant demand for the enhancement of the practical side of legal education, and the Hungarian students are open to this qualitatively new and complex form of legal education. It is highly probable that newer legal clinics will be created in the future, if the dynamics of this process remain the same.

9. In addition to the seminary education and the work of legal clinics there are some other opportunities, which could also include certain practical elements. First of all, the so-

\footnotetext{
40 For the details see ibid.

41 Ibid.

42 http://tasz.hu/jogklinika
} 
called pleading competitions ${ }^{43}$ should be mentioned. Both, law schools and governmental agencies organize competitions e.g. the Criminal Law Pleading Competition of University of Miskolc Faculty of Law could be regarded as a tradition, since it has been organized for many years. ${ }^{44}$ But one can find many other pleading competitions, too e.g. the pleading competitions organized by various Bar Associations ${ }^{45}$ or the national Labour Law pleading competition. Additionally, the University of Miskolc has also been organizing a European law moot court competition in Hungarian since 2004, which might be regarded as a preparatory step toward the international moot court competitions. These competitions offer wide-ranging challenges for law students by which they can improve their speech making, public speaking and performance skills.

\section{Concluding thoughts}

10. Primarily one can easily recognize that the amount of practical education has considerably increased in the Hungarian legal education system during the last few years. Law schools are more and more willing to provide various courses focused on certain segments of practice. The most comprehensive practical education is undoubtedly granted by the numerous legal clinics which exist to provide a detailed knowledge based on theory, skills and supervised but independent partice. Compared to the clinical legal education method the system of seminars has somehow slightly more modest goals, concentrating on the presentation of the relevant national, or in case of International Law or "European Law", international case-law. By reading and discussing judicial decisions many skills of law students could be improved, for example reading and interpreting cases, distinguishing between legally relevant and irrelevant facts, understanding and following legal reasoning etc.. In addition, the mandatory externship period is also able to familiarize students with the everyday work of a given law firm or governmental agency so that they can broaden their view on real functioning law.

However, this considerable expansion of practice in the legal education does need refining. Regarding the legal clinics, it must be emphasized that only half of the law schools use this innovative form of legal education and they are only accessible to a limited number of students, the others have not established legal clinics so far. It should be incumbent upon the other faculties to start these clinics in their curricula since the lack of clinical legal education could be a reason for serious student deficiencies. This lack may deprive a considerable number of students of the complex practical experience provided by this form of education, and it could even affect their chances in the labour market. The lack of legal clinics could also be a problem for the faculties themselves due to the very severe competition within the legal educational system. It is obvious that the work of legal clinics can offer a more advantageous position to a faculty since it can then argue that it provides a

43 It is worthwhile knowing that these pleading or orator competitions differ from the so-called moot-court competitions, as for instance, the Philip c. Jessup International Law Moot Court Competition, in certain points. In Hungary the pleading competitions are focused on individual pleading in front of a bench, that is to say, on the individual eloquence and skills in public speaking. Participants are required neither to form teams, nor prepare and submit memorials, they only have to plead before a bench consisting of professionals.

$44 \mathrm{http}: / /$ www.mertnet.net/cikkek/2008/aktualis/perbeszedverseny-2008

45 For instance by the Bar Association of the County of Bács-Kiskun, cf. http://www.bacskiskunmegyeiugyvedikamara.hu/index.php?option $=$ com_content\&task=view\&id=63\&Itemid=1 
much more comprehensive education to students than the others, and it could even be the decisive point when someone chooses a law school.

Another problem regarding the practical education could be the fact that law schools, even those who provide clinical legal education, do not put serious emphasis on skilltraining in a broad sense. Seminars concentrate on the discussion of case-law, the mandatory externship period and legal clinics intend to introduce students to the everyday practice of legal work, but nothing-or almost nothing-is devoted to improving the general skills of students. Take for example rhetoric, which should be regarded as one of the most important skills of a lawyer, due to the fact that argument has an eminent role in legal culture, ${ }^{46}$ is only included in the curriculum of two law schools as an elective course. ${ }^{47}$ Other faculties do not teach it at all. Professional ethics or ethics has a slightly broader role, but these courses are only introductory classes at the beginning of the legal education and they are usually parts of more comprehensive philosophy courses. ${ }^{48}$ Needless to say it is important for a lawyer to have a solid ethical education since his or her profession has to make difficult and complex decisions. Otherwise, studying professional or at least general ethics is important from the point of view of empathy since it facilitates the understanding of human motives and decisions. On the whole, the practical side of Hungarian legal education should be completed with such subjects, which can enable law students to master these basic skills of their future profession that are not explicitly related to caselaw or everyday legal work but extremely important in the ethos of lawyers such as logical thinking, public speaking or human understanding. ${ }^{49}$

11. As an epilogue, the points outlined above are re-enforced by an empirical survey taken among the students of the University of Szeged Faculty of Law in $2002 .^{50}$ This research concentrated on the factors influencing legal education and its conclusions revealed certain interesting findings on the role of practice in legal education from the student's perspective. In this study the researchers asked fifty randomly chosen students from the third year to list and explain such things with which they were dissatisfied, concerning their education. This survey did not apply any questionnaire therefore enabling the students to

46 James Boyd White argues that the work of the rhetorician and the lawyer is very close to each other in many senses. Moreover, law or legal practice could also be conceived of a special branch of rhetoric. Thus rhetoric should play a primordial role in legal education with special regard to skilltraining. Cf. White, J. B.: Rhetoric and Law. The Arts of Cultural and Communal Life. In: James, B. W.: Heracles's Bow. Essays on the Rhetoric and Poetics of Law. Wisconsin, 1985. 32-35.

47 At the University of Szeged Faculty of Law and Károli Gáspár University Faculty of Law.

48 The volume of János Zlinszky-professor emeritus of Roman Law at the Pázmány Péter Catholic University Faculty of Law and Political Sciences-could be regarded as a symbol of that approach which treats legal ethics as a separate subject. Cf. Zlinszky J.: Keresztény erkölcs és jogászi etika [Christian Morals and Legal Ethics]. Budapest, 1998.

49 There is one very innovative initiative in this field. Miklós Szabó-Dean of University of Miskolc Faculty of Law and Head of Legal Theory and Sociology of Law Department-published a course-book entitled Trivium at the beginning of 2000. This book concentrates on the improvement of such elementary skills which are related to language in the broadest sense, such as grammar, logic and rhetoric. Cf. Szabó M.: Trivium. Grammatika, logika, retorika joghallgatók számára [Trivium. Grammar, Logic and Rhetoric for Law Students]. Miskolc, 2001.

50 Nagy Zs.-Tóth J. Z.: A jogi oktatás helyzete (Felmérés a jogi oktatást befolyásoló tényezőkről) [The Situation of Legal Education (A Survey on those Factors which can Influence Legal Education)]. Jogelméleti Szemle 2002/4. http://jesz.ajk.elte.hu/nagy12.html 
formulate their own opinions without any external influence encoded into the phrasing of questions. ${ }^{51}$

The participants generally touched on six different problems in their replies. According to the researchers on the basis of these replies it is possible to classify seven factors which influence the effectiveness of legal education. The most important three factors are the number of students, the subjectivity of examinations, and the problems of teaching methods. ${ }^{52}$ With regard to the methodology of teaching, 54 percent of the students mentioned the lack of practical legal education as a serious deficiency. In their eyes the general legal education is excessively theory oriented, which means that professors and teachers are only concerned with the discussion of abstract concepts and do not concentrate on the practical dimension of law. Students were also highly critical of the system of seminary education; they unequivocally complained that many of these seminars cannot be regarded as more than "mini lectures" or they even miss the discussion of case-law because of the endless explanations of the teacher. Some students also pointed out that verbal communication has only a secondary place in legal education due to the fact that most of the exams are written and seminars are also mostly about making notes on the basis of the explanation of the teacher. ${ }^{53}$

Consequently, students are also aware of the many deficiencies of the practical legal education system, and this can be regarded as good news in itself. The explicit or implicit expectations of law students might also be a factor which may compel law schools to integrate more and more practical elements into their curricula in the long run.

11. In conclusion, the field of practical education in the system of Hungarian legal education is in a transitory phase. ${ }^{54}$ Transitory since many new and inventive elements have already appeared e.g. legal clinics or the teaching of rhetoric, but they have not extended generally so far. Hopefully, this transition signals an unambiguous advance towards a much more modern form of legal education in which practice in the broadest sense will have a more balanced position compared to the theoretical oriented teaching. It should be borne in mind however that the roots of the Hungarian legal education are deeply interconnected to the continental, dogmatic approach, which does not intend to prepare law students for the challenges of practical life, but concentrates on providing lawyers with a broad intellectual background. ${ }^{55}$ It might be illusory to anticipate a complete reform of the Hungarian legal education on the basis of the "practical"-originally North-American-model, but the growth of different forms of practical education is certainly a positive step towards the formation of a system of legal education where the theoretical and practical dimensions could work in harmony.

51 Ibid.

52 Ibid.

53 Ibid.

54 For a broader discussion of the relationship between socio-political transition and Hungarian legal thinking see: Meleg Cs.: Társadalmi változások és jogászi gondolkodásmód [The Impact of Social Changes on the Legal Way of Thinking]. Jura 2001/2, 58-73.

55 René David, classic of modern comparative law literature, explicitly argues that the task of legal education is the teaching of general legal culture since law students in this system could acquire such a broad view of legal problems which protects them to become simple bureaucrats and comparative law must play a preeminent role in it. Cf. David, R.: Le droit comparé enseignement de culture general. Revue Internationale de Droit Comparé 2 (1950) 682-685. 